\title{
ANALISA SISTEM RESERVASI TIKET PADA PT XYZ
}

\author{
Alcianno G. Gani \\ Universitas Dirgantara Marsekal Suryadarma \\ localghost2000@gmail.com
}

\begin{abstract}
ION
The use of the computer and its systems has become a major necessity to improve the the company performance. Each of the company's manual processes can be subtituted by computers because of the provision of more sophisticated information and to support the decision making process undertaken by management. PT XYZ is engaged in serving the Tourism Services Business travel and requested by one airline of Saudi Arabia, AIR NAS (National Air Service) to become a GSA (Ground Service Agent) official in Indonesia on 19 November 2012. As Ground Service Agent (GSA), PT XYZ serves Umrah flight ticket sales. In the system analysis conducted by the author is found a problems in the system include: the lack of a computerized and automation systems that can make the work more efficient, the reservation process is still done manually so that the customer must come to the office, the process of checking and inputting the data of available seat still done manually cause inefficient of time, the manual reporting process by collecting data from payment and ticket printing so spend much time, the ticket printing process is inefficient because after paying the consumer must return again to the reservation. In order to minimize the existing problems, it is needed to develop information systems and computerized ticket reservation web-based in PT XYZ

Keywords: Information System, Analyse, Reservations, Tickets
\end{abstract}

\footnotetext{
Penggunaan komputer dan sistem-sistemnya sudah menjadi kebutuhan yang utama dalam rangka meningkatkan kinerja suatu Perusahaan. Setiap proses manual dari perusahaan dapat digantikan oleh komputer karena penyediaan informasi yang lebih canggih serta dapat mendukung proses pengambilan keputusan yang dilakukan oleh manajemen. PT XYZ bergerak di bidang Usaha Jasa Pariwisata yang melayani perjalanan wisata dan pada 19 November 2012 diminta/dipilih oleh salah satu maskapai penerbangan dari Saudi Arabia yaitu NAS AIR (National Air Service) untuk menjadi GSA (Ground Service Agent) resmi di Indonesia. Sebagai Ground Service Agent (GSA), PT XYZ melayani seluruh penjualan tiket penerbangan Umroh. Pada analisa sistem yang dilakukan penulis ditemukan permasalahan pada sistem antara lain: belum adanya sistem yang terkomputerisasi dan otomatis yang dapat membuat pekerjaan lebih efisien, proses reservasi masih dilakukan secara manual sehingga konsumen harus datang ke kantor, proses pengecekan dan penginputan data available seat masih dilakukan secara manual menyebabkan tidak adanya efisiensi waktu, proses pembuatan laporan masih manual dengan mengumpulkan data dari pembayaran dan pencetakan tiket, sehingga menghabiskan cukup banyak waktu, proses pencetakan tiket yang tidak efisien karena setelah membayar, konsumen harus kembali lagi ke bagian reservasi. Dalam rangka meminimalkan permasalahan yang ada maka perlu adanya pengembangan sistem informasi reservasi tiket yang terkomputerisasi dan berbasis web pada PT XYZ.
}

Kata Kunci: Sistem Informasi, Analisa, Reservasi, Tiket 


\section{PENDAHULUAN}

Di era globalisasi seperti saat ini dunia teknologi dan informasi perkembangannya sangat pesat, khususnya dunia komputer. Komputer saat ini merupakan kebutuhan manusia di dalam melakukan berbagai kegiatan, ditambah dengan adanya teknologi informasi yang semakin berperan di dalam dunia pekerjaan (Muryan Awaludin dan Natasya, 2018). Dengan menggunakan piranti teknologi informasi yang tepat, maka akan dihasilkan informasi yang tepat dan akurat sesuai dengan kebuutuhan sehingga keputusan dapat diambil dengan cepat. Dengan demikian meluasnya kegiatan dan kebutuhan manusia semakin membutuhkan komputer guna menyelesaikan masalah dan kegiatan dengan cepat dan akurat hal ini pula yang dirasakan oleh perusahaan besar maupun perusahaan yang sedang berkembang. Penggunaan komputer dan sistemsistemnya sudah menjadi kebutuhan yang utama dalam rangka meningkatkan kinerja suatu Perusahaan. Setiap proses manual dari perusahaan dapat digantikan oleh komputer karena penyediaan informasi yang lebih canggih serta dapat mendukung proses pengambilan keputusan yang dilakukan oleh manajemen.

Namun pada kenyataannya masih banyak perusahaan-perusahaan yang menggunakan sistem yang belum terkomputerisasi dengan baik. Dengan menggunakan komputer, perusahaan dapat melakukan proses penyimpanan data dengan mudah dan cepat, karena tingkat kecepatan dan penyimpanan data pada komputer lebih aman dan rapi, sehingga mudah menemukan kembali data yang diinginkan. Dengan adanya sistem informasi maka perusahaan akan mengetahui hasil kegiatan usahanya atau pendapatannya melalui sub bagian dari sistem tersebut.

\section{Metode Penelitian}

1. Wawancara. Wawancara dilakukan guna mendapatkan informasi mengenai semua kegiatan yang berhubungan dengan reservasi tiket pada PT XYZ.

2. Pengamatan. Dari kegiatan observasi ini dapat diketahui proses dari kegiatan reservasi tiket pada PT XYZ.

3. Studi Pustaka. Studi pustaka dilakukan melalui literatur-literatur atau referensi-referensi yang ada diperpustakaan-perpustakaan dan referensi-referensi dari internet.

\section{PEMBAHASAN \\ Pengertian Sistem}

Sistem adalah suatu jaringan kerja dari prosedur-prosedur yang saling berhubungan, berkumpul bersama-sama untuk melakukan suatu kegiatan atau untuk menyelesaikan suatu sasaran tertentu. Dalam definisi yang paling umum, sebuah sistem adalah sekumpulan objek atau benda yang memiliki hubungan diantara mereka.

Pengertian sistem menurut Jogiyanto adalah "suatu jaringan kerja dari prosedur-prosedur yang saling berhubungan, berkumpul bersama-sama untuk melakukan suatu kegiatan atau untuk menyelesaikan suatu sasaran yang tertentu. Pendekatan sistem yang lebih menekankan pada prosedur mendefinisikan sistem adalah suatu jaringan kerja dari prosedur-prosedur yang saling berhubungan, berkumpul bersama-sama untuk melakukan suatu kegiatan atau untuk menyelesaikan suatu sasaran tertentu. Sedangkan pendekatan sistem yang lebih menekankan pada elemen atau komponennya mendefinisikan sistem adalah kumpulan dari elemen-elemen yang berinteraksi 
untuk mencapai suatu tujuan tertentu" (Jogiyanto, 2005:1-2).

Menurut O'Brien: “Sistem adalah sekelompok komponen yang saling berhubungan, bekerja sama untuk menghasilkan tujuan bersama dengan menerima masukan dan menghasilkan keluaran dalam suatu proses transformasi yang teratur" (O'Brien, 2006:29)

Menurut Wasson: "Sistem adalah sekumpulan integrasi elemen yang dapat saling dijalankan, masing-masing dengan kapabilitas yang dibatasi dan dispesifikasikan secara nyata, bekerja sinergis membentuk proses bernilai yang bertujuan memungkinkan user untuk memuaskan kebutuhan operasional berorientasi misi dalam lingkungan operasi yang sudah ditentukan dengan sebuah hasil dan kemungkinan keberhasilan yang ditentukan" (Wasson, 2005:18).

Jadi dapat disimpulan bahwa suatu sistem merupakan jaringan kerja dari prosedur-prosedur atau bagiannya yang saling berinteraksi, saling berhubungan dan saling ketergantungan, berkumpul bersama-sama untuk membentuk satu kesatuan dalam mencapai tujuan tertentu.

\section{Karakteristik Sistem}

Karakteristik sistem adalah sistem yang mempunyai komponen-komponen, batas sistem, lingkungan sistem, penghubung, masukan, keluaran, pengolahan dan sasaran (Jogiyanto, 2005:684).

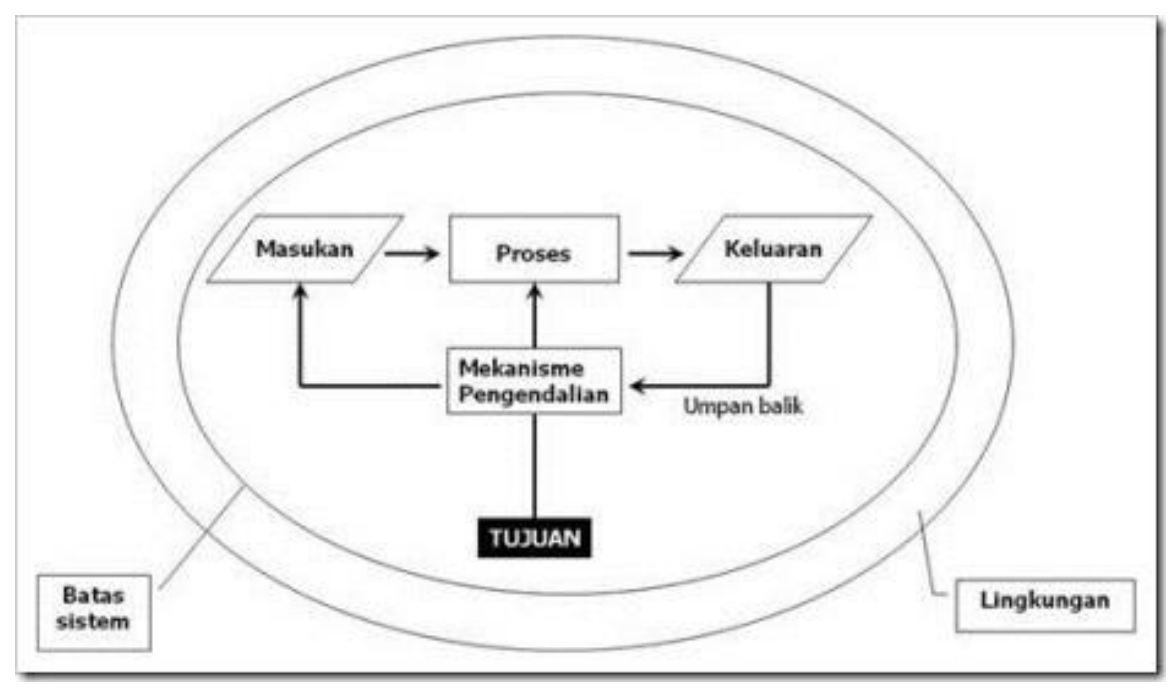

Gambar Karakteristik Sistem

Dari gambar diatas dpata dijelaskan bahwa karakteristik system dapat dibagi menjadi delapan bagian yaitu:

1. Komponen Sistem (Components)

Suatu sistem terdiri dari sejumlah komponen yang saling berinteraksi Yang artinya saling bekerja sama membentuk satu kesatuan. Komponen-komponen sistem atau elemen-elemen sistem dapat berupa suatu subsistem atau bagian-bagian dari sistem. Setiap sistem tidak perduli betapapun kecilnya, selalu mengandung komponen-komponen atau subsistem-subsistem. Setiap subsistem mempunyai sifat-sifatdari sistem untuk menjalankan suatu fungsi tertentu dan mempengaruhi proses sistem secara keseluruhan. Jadi, dapat dibayangkan jika dalam 
suatu sistem ada subsistem yang tidak berjalan/berfungsi sebagaimana mestinya. Tentunya sistem tersebut tidak akan berjalan mulus atau mungkin juga sistem tersebut rusak sehingga dengan sendirinya tujuan sistem tersebut tidak tercapai.

2. Batas Sistem (boundary)

Merupakan daerah yang membatasi antara suatu sistem dengan sistem yang lainnya atau dengan lingkungan luarnya. Batas sistem ini memungkinkan suatu sistem dipandang sebagai satu kesatuan. Batas suatu sistem menunjukkan ruang lingkup (scope) dari sistem tersebut.

3. Lingkungan Luar Sistem (environments)

Lingkungan luar dari suatu sistem adalah apapun diluar batas dari sistem yang mempengaruhi operasi sistem. Lingkungan luar sistem dapat bersifat menguntungkan dan dapat juga bersifat merugikan sistem tersebut. Lingkungan luar yang menguntungkan merupakan energi dari sistem dan dengan demikian harus tetap dijaga dan dipelihara. Sedang lingkungan luar yang merugikan harus ditahan dan dikendalikan, kalau tidak maka akan menggangu kelangsungan hidup dari sistem.

4. Penghubung Sistem (interface)

Penghubung sistem merupakan media penghubung antara satu subsistem dengan subsistem lainnya. Melalui penghubung ini memungkinkan sumber-sumber daya mengalir dari satu subsistem ke yang lainnya. Keluaran (output) dari satu subsistem akan menjadi masukan (input) untuk subsistem lainnya dengan melalui penghubung. Dengan penghubung satu subsistem dapat berintegrasi dengan subsistem yang lainnya membentuk satu kesatuan.
5. Masukan Sistem (input)

Masukan sistem adalah energi yang dimasukkan ke dalam sistem. Masukan dapat berupa masukan perawatan (maintenance input) dan masukan sinyal (signal input). Maintenance input adalah energi yang dimasukkan supaya sistem tersebut dapat beroperasi. Signal input adalah energi yang diproses untuk didapatkan keluaran. Sebagai contoh didalam sistem komputer, program adalah maintenance input yang digunakan untuk mengoperasikan komputernya dan data adalah signal input untuk diolah menjadi informasi.

6. Keluaran Sistem (output)

Keluaran sistem adalah hasil dari energi yang diolah dan diklasifikasikan menjadi keluaran yang berguna dan sisa pembuangan. Keluaran dapat merupakan masukan untuk subsistem yang lain atau kepada super sistem. Misalnya untuk sistem komputer, panas yang dihasilkan adalah keluaran yang tidak berguna dan merupakan hasil sisa pembuangan, sedang informasi adalah keluaran yang dibutuhkan.

7. Pengolah Sistem (process)

Suatu sistem dapat mempunyai suatu bagian pengolah yang akan merubah masukan menjadi keluaran. Suatu sistem produksi akan mengolah masukan berupa bahan baku dan bahan-bahan yang lain menjadi keluaran berupa barang jadi. Sistem akuntansi akan mengolah data-data transaksi menjadi laporan-laporan keuangan dan laporan-laporan lain yang dibutuhkan oleh manajemen.

8. Sasaran (objectives) atau Tujuan (goal)

Suatu sistem pasti mempunyai tujuan atau sasaran. Kalau suatu sistem tidak mempnyai sasaran, maka operasi sistem tidak akan ada 
gunanya. Sasaran dari sistem sangat menentukan sekali masukan yang dibutuhkan sistem dan keluaran yang akan dihasilkan sistem. Suatu sistem dikatakan berhasil bila mengenai sasaran atau tujuannya. Perbedaan suatu sasaran (objectives) dan suatu tujuan (goal) adalah, "tujuan" biasanya dihubungkan dengan ruang lingkup yang lebih luas dan "sasaran" dalam ruang lingkup yang lebih sempit. Bila merupakan suatu sistem utama, seperti misalnya sistem bisnis perusahaan, maka istilah "goal" lebih tepat diterapkan. Untuk sistem akuntansi atau sistemsistem lainnya yang merupakan bagian atau subsistem dari sistem bisnis, maka istilah "objectives" yang lebih tepat. Jadi tergantung dari ruang lingkup mana memandang sistem tersebut. Seringkali tujuan (goal) dan sasaran (objectives) digunakan bergantian dan tidak dibedakan.

\section{Klasifikasi Sistem}

a. Sistem Abstrak (Abstract System) dan Sistem Fisik (Physical System).

Sistem abstrak adalah sistem yang berupa pemikiran atau ide-ide yang tidak tampak secara fisik. Misalnya sistem teologia, yaitu sistem yang berupa pemikiran-pemikiran hubungan antara manusia dengan Tuhan. Sistem fisik merupakan sistem yang ada secara fisik. Misalnya sistem komputer, sistem akuntansi, sistem produksi dan lain sebagainya.

b. Sistem Ilmiah (Natural System) dan Sistem Buatan Manusia (Human Made System).

Sistem alamiah adalah sistem yang terjadi melalui proses alam, tidak dibuat manusia. Misalnya sistem perputaran bumi atau system tatasurya. Sistem buatan manusia adalah sistem yang dirancang oleh manusia.
Sistem buatan manusia yang melibatkan interaksi antara manusia dengan mesin disebut dengan humanmachine System atau ada yang menyebut dengan man-machine System. Sistem informasi merupakan contoh man-machine System, karena menyangkut penggunaan komputer yang berinteraksi dengan manusia.

c. Sistem Tertentu (Deterministic System) dan Sistem Tak Tentu (Probabilistic System).

Sistem tertentu beroperasi dengan tingkah laku yang sudah dapat diprediksi. Interaksi diantara bagianbagiannya dapat dideteksi dengan pasti, sehingga keluaran dari sistem dapat diramalkan. Sistem komputer adalah contoh dari sistem tertentu yang tingkah lakunya dapat dipastikan berdasarkan program-program yang dijalankan. Sistem tak tentu adalah sistem yang kondisi masa depannya tidak dapat diprediksi karena mengandung unsur probabilitas.

d. Sistem Tertutup (Closed System) dan Sistem Terbuka (Open System)

Sistem tertutup merupakan sistem yang tidak berhubungan dan tidak terpengaruh dengan lingkungan luarnya. Sistem ini bekerja secara otomatis tanpa adanya turut campur tangan dari pihak diluarnya. Secara teoritis sistem tertutup ini ada, tetapi kenyataannya tidak ada sistem yang benar-benar tertutup, yang ada hanyalah relatively closed Sistem (secara relatif tertutup, tidak benarbenar tertutup). Sistem terbuka adalah sistem yang berhubungan dan terpengaruh dengan lingkungan luarnya. Sistem ini menerima masukan dan menghasilkan keluaran untuk lingkungan luar atau subsistem yang lainnya. Karena sistem sifatnya terbuka dan terpengaruh oleh lingkungan luarnya, maka suatu sistem harus mempunyai suatu sistem 
pengendalian yang baik. Sistem yang baik harus dirancang sedemikian rupa, sehingga secara relatif tertutup karena sistem tertutup akan bekerja secara otomatis dan terbuka hanya untuk pengaruh yang baik saja.

Klasifikasi sistem terbuka dan tertutup dapat digambarkan sebagai berikut:

(a)

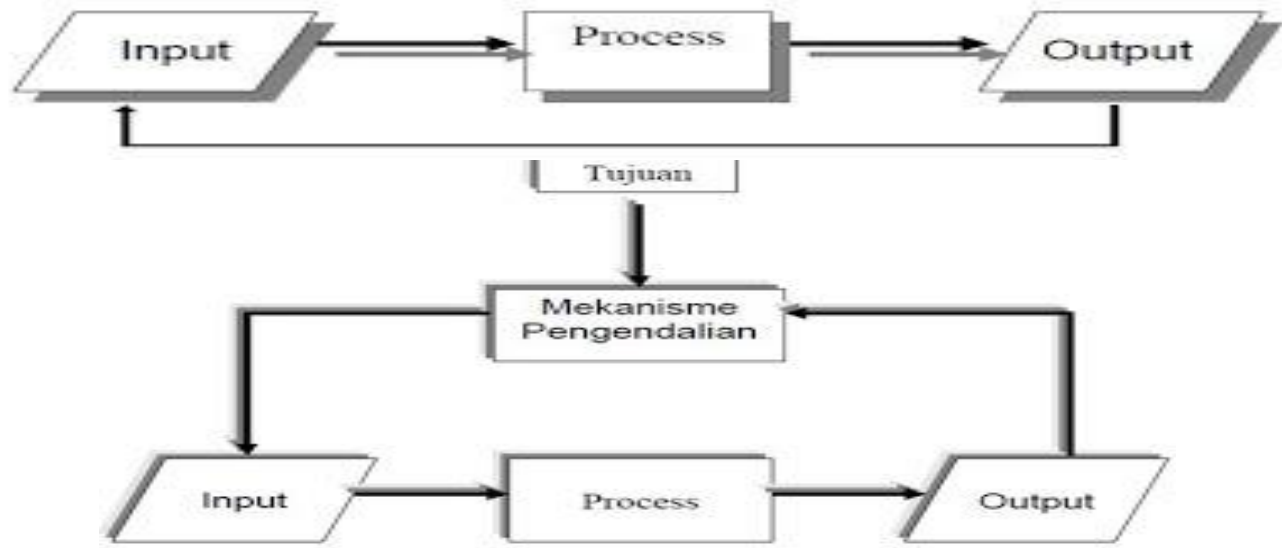

(b)

Gambar Sistem Terbuka (a), Sistem Tertutup (b)

Sistem terbuka adalah sistem yang dihubungkan dengan lingkungannya melalui arus sumber daya. Sistem tertutup adalah sistem yang tidak dihubungkan dengan lingkungannya.

\section{Daur Hidup Sistem}

Daur Hidup Sistem merupakan tahapan-tahapan didalam pembentukan sebuah sistem, yang terdiri atas beberapa fase antara lain:

a. Fase memahami kebutuhan.

Sebelum segala sesuatunya dilakukan, maka yang pertama kali yang harus dikenali/dipahami adalah kebutuhan atau masalah yang ada secara tepat. Masalah atau kebutuhan tersebut muncul karena perkembangan organisasi yang menyebabkan transaksi-transaksi meningkat, agar pengembangan sistem dapat berjalan secara efisien dan efektif maka setiap permasalahan yang ada harus didefinisikan dengan jelas dan tepat.

b. Fase Pengembangan Sistem.
Fase ini merupakan proses yang terdiri atas prosedur-prosedur yang dilaksanakan guna menganalisis kebutuhan yang muncul, kemudian mulai membangun sistem sebagian saja atau seluruhnya guna memenuhi kebutuhan tersebut.

c. Fase Pengembangan Sistem.

Merupaka fase peralihan dari fase pengambangan sistem ke fase operasional (atau merupakan langkah akhir dari pengembangan sistem).

d. Fase Pengoperasian Sistem. Operasi sistem harus bersifat dinamis menyesuaikan diri dengan pertumbuhan bisnis, perubahan peraturan, kebijaksanaan baru perkembangan baru.

e. Fase Sistem Menjadi Usang.

Perubahan-perubahan yang terjadi secara drastis menyebabkan sistem tidak dapat mengikuti perubahan kemudian tidak dapat ditanggulangi dengan perbaikan saja, tetapi secara teknis dan ekonomis layak diganti dengan sistem yg baru. 


\section{Konsep Dasar Sistem Informasi Pengertian Informasi}

Pengertian Informasi menurut H. M. Jogianto (2005:8), dalam buku analisis dan desain sistem informasi "Informasi adalah data yang diolah menjadi bentuk yang lebih berguna dan lebih berarti bagi yang menerimanya".

Secara umum informasi dapat didefinisikan sebagai hasil dari pengolahan data dalam suatu bentuk yang lebih berguna dan lebih berarti bagi penerimanya yang menggambarkan suatu kejadiankejadian yang nyata yang digunakan untuk pengambilan keputusan.

Sumber dari informasi adalah data. Data adalah kenyataan yang menggambarkan suatu kejadian-kejadian dan kesatuan nyata. Kejadian-kejadian adalah sesuatu yang terjadi pada saat tertentu. Di dalam dunia bisnis, kejadiankejadian yang sering terjadi adalah transaksi perubahan dari suatu nilai yang disebut transaksi. Kesatuan nyata adalah berupa suatu obyek nyata seperti tempat, benda dan orang yang betul-betul ada dan terjadi.

Data merupakan bentuk yang masih mentah, belum dapat bercerita banyak sehingga perlu diolah lebih lanjut. Data diolah melalui suatu metode untuk menghasilkan informasi. Data dapat berbentuk simbol-simbol semacam huruf, angka, bentuk suara, sinyak, gambar dan sebagainya.

Data yang diolah melalui suatu model menjadi informasi, penerima kemudian menerima informasi tersebut, membuat suatu keputusan dan melakukan tindakan yang berarti menghasilkan suatu tindakan yang lain yang akan membuat sejumlah data kembali. Data tersebut akan ditangkap sabagai input, diproses kembali lewat suatu model dan seterusnya membentuk suatu siklus.

Siklus informasi ini dapat digambarkan sebagai berikut :

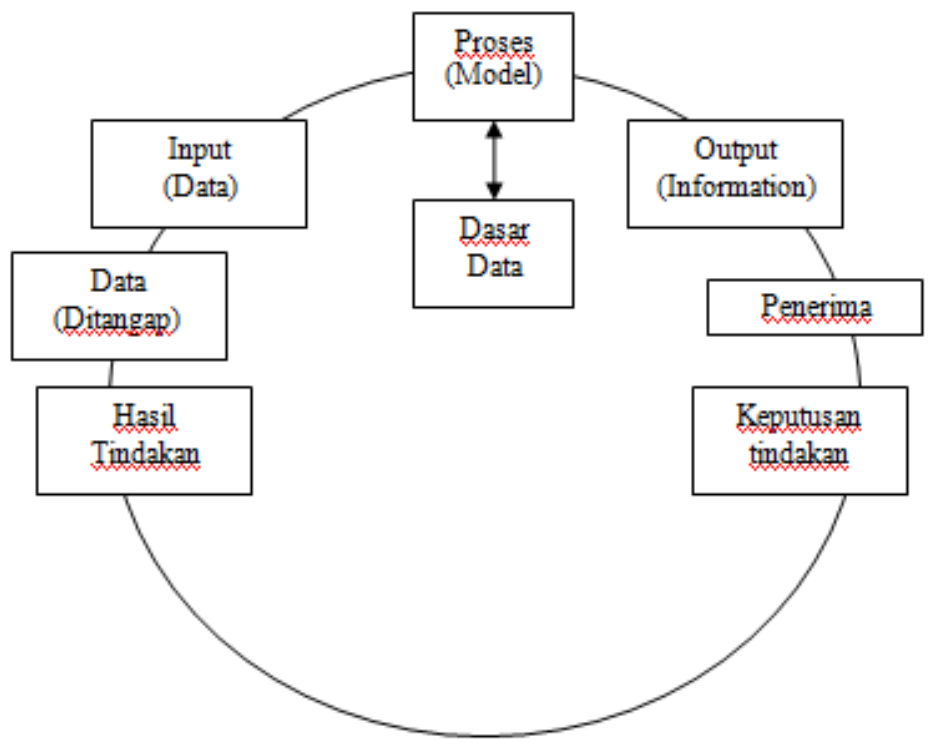

Gambar Gambar Siklus Informasi

(Tata Sutabri, S.Kom., MM, 2005:21) 


\section{Kualitas Informasi}

Tiga hal penting yang menjadi dasar dalam menentukan kualitas sistem informasi (Kristanto, 2008:17) yaitu:

a. Akurat, berarti informasi harus bebas dari kesalahan-kesalahan dan tidak menyesatkan bagi orang yang menerima informasi tersebut. Dalam prakteknya, mungkin dalam penyampaian suatu informasi banyak sekali gangguan-gangguan yang datang yang dapat merubah isi dari informasi tersebut.

b. Tepat waktu, informasi yang diterima harus tepat pada waktunya, sebab kalau informasi yang diterima terlambat maka informasi tersebut sudah tidak berguna lagi. Informasi yang yang using tidak tidak mempunyai nilai yang baik, sehingga kalau tidak sebagai dasar dalam pengambilan keputusan akan berakibat fatal atau kesalahan dalam keputusan dan tindakan.

c. Relevan, informasi harus mempunyai manfaat bagi si penerima, sebab informasi ini akan digunakan untuk pengambilan suatu keputusan dalam pemecahan suatu permasalahan. Relevansi informasi untuk tiap-tiap orang satu dengan lainnya berbeda.

\section{Pengertian Sistem Informasi}

Sistem informasi adalah suatu sistem di dalam suatu organisasi yang mempertemukan kebutuhan pengolahan transaksi harian, mendukung operasi, bersifat manajerial dan kegiatan strategi dari suatu organisasasi, dan menyediakan pihak luar tertentu dengan laporanlaporan yang diperlukan. (Analisis dan Desain Sistem Informasi, Jogiyanto, 2005:11).

Sistem informasi terdiri dari komponen-komponen yang disebut dengan istilah blok bangunan (building block). Sebagai suatu dari sistem dari keenam blok tersebut masing-masing saling berinteraksi satu dengan yang lainnya untuk membentuk satu kesatuan. (Analisis dan Desain Sistem Informasi, Jogiyanto, 2005:15).

Komponen - komponen / blok tersebut yaitu :

a. Blok masukan (input).

Blok masukan ini mewakili data yang masuk kedalam sistem informasi.Input disini termasuk Metode-metode dan media untuk menangkap data yang akan dimasukan, yang dapat berupa dokumen - dokumen dasar.

b. Blok Model.

Blok ini terdiri dari kombinasi prosedur,logika dan model matematika yang akan memanipulasi data input dan data yang tersimpan di basis data dengan cara yang sudah tertentu untuk menghasilkan keluaran yang diinginkan.

c. Blok keluaran (output).

Produk dari sistem informasi adalah keluaran yang merupakan informasi yang berkualitas dan dokumentasi yang berguna untuk semua tingkat manajemen serta semua pemakai sistem.

d. Blok Teknologi.

Teknologi merupakan alat yang digunakan untuk menerima masukan,menjalankan model,menyimpan dan mengakses data,menghasilkan dan mengirimkan keluaran dan membantu pengendalian dari sistem secara keseluruhan. Teknologi terdiri dari 3 bagian utama, yaitu Teknisi,perangkat lunak (software) dan perangkat keras (hardware).

e. Blok Basis Data.

Basis data merupakan kumpulan data yang saling berhubungan satu 
dengan yang lainnya, tersimpan diperangkat keras computer, basis data diakses atau dimanipulasi dengan menggunakan paket perangkat lunak yang disebut Data Base Management System (DBMS).

f. Blok kendali.

Beberapa pengendalian perlu dirancang dan diterapkan untuk meyakinkan bahwa hal-hal yang dapat merusak sistem bisa dicegah ataupun bila terlanjur terjadi kesalahan-kesalahan dapat langsung cepat diatasi.

Sistem informasi yang dikembangkan berbasis teknologi komputer dibedakan menjadi beberapa tipe aplikasi (Barsasella, 2010:9), yaitu:

a. Transaction Processing System (TPS).

Adalah sistem informasi terkomputerisasi yang dikembangkan untuk memproses sejumlah besar data untuk transaksi bisnis rutin.

b. Management Information System (MIS).

Adalah sebuah sistem informasi pada level manajemen yang berfungsi untuk membantu perencanaan, pengendalian, dan pengambilan keputusan dengan menyediakan resume rutin dan laporan-laporan tertentu.

c. Decision Support System (DSS).

Adalah sebuah sistem informasi pada level manajemen dari suatu organisasi yang mengombinasikan data dan model analisis canggih atau peralatan data analisis untuk mendukung pengambilan yang semi terstruktur dan tidak terstruktur.

d. Expert System (ES).

Adalah sebuah sistem informasi yang merupakan representasi pengetahuan yang menggambarkan cara seorang ahli dalam mendekati atau memecahkan suatu masalah.

\section{Sistem Manajemen Basis Data.}

McLeod (2008:26) dalam bukunya menyatakan bahwa sistem manajemen basis data (Database Management System - DBMS) adalah suatu aplikasi peranti lunak yang menyimpan struktur basis data, data itu sendiri, hubungan di antara data dalam basis data, dan nama-nama formulir, jenis-jenis data, angka di belakang decimal, jumlah karakter, nilainilai default, dan seluruh uraian field lainnya.

Pendekatan basis data menawarkan keunggulan-keunggulan dibandingkan dengan pemrosesan berkas tradisional. Keunggulan-keunggulan itu sebagai berikut:
a. Kemandirian program dan data
b. Mengurangi pengulangan data (redundansi) yang tidak perlu
c. Memperbaiki konsistensi data
d. Memperbaiki kesempatan berbagi data (data sharing)
e. Menambah produktivitas pengembangan program aplikasi
f. Memaksakan standar
g. Memperbaiki kualitas data
h. Memperbaiki akses data
i. Mengurangi biaya pemeliharaan program

\section{Pengertian Sistem Informasi Reservasi}

Reservasi adalah sebuah proses perjanjian berupa pemesanan sebuah produk baik barang maupun jasa, di mana pada saat itu telah terdapat kesepahaman antara konsumen dengan produsen mengenai produk tersebut namun belum ditutup oleh sebuah transaksi jual-beli. Pada saat reservasi berlangsung, biasanya ditandai dengan adanya proses tukar menukar informasi antara konsumen dan 
produsen agar kesepahaman mengenai produk dapat terwujud.

Beberapa contoh dari reservasi adalah sebagai berikut :

1. Reservasi

tiket

penerbangan/pesawat.

2. Reservasi kamar hotel.

3. Reservasi tiket kereta Api.

4. Reservasi tiket bus.

Reservasi pemesanan tiket penerbangan adalah sebuah proses pemesanan salah satu produk yang dijual oleh perusahaan penerbangan pengangkut penumpang, yaitu berupa dokumen perjalanan yang berfungsi sebagai tanda bahwa pemegang dokumen tersebut berhak atas fasilitas pengantaran dari satu daerah ke daerah lain.

Proses reservasi pemesanan tiket penerbangan dapat terjadi pada :

a. Lokasi penjualan (points of sales) tiket penerbangan yang langsung dikelola oleh perusahaan penerbangan itu sendiri (ex: Town Office, Airport).

b. Biro perjalanan wisata (Travel Agent).

c. Media Pembantu (ex: call center, SMS broadcast, website).

d. Perusahaan rekanan.

\section{Macam-macam Reservasi}

a. Reservasi Perorangan (Individual Reservation)

Individual reservation adalah pemesanan untuk seorang, pasangan, atau sebuah keluarga. Reservasi ini biasanya dilakukan sendiri oleh calon pembeli atau agen.

b. Reservasi Rombongan/Tour (Group/Tour Reservation)

Group/Tour Reservation adalah pemesanan yang umumnya dibuat oleh agen/biro perjalanan untuk para pelanggannya. Pesanan dibuat untuk yang datang berombongan. Seringkali harga yang diberikan adalah harga diskon (Discounted Rates/Group Rates).

c. Reservation

(Conference Reservation)

Conference reservation adalah pemesanaan untuk sebuah rombongan yang akan melakukan eksibisi atau pertemuan. Reservasi ini umumnya dibuat oleh sebuah organisasi, perusahaan, atau suatu asosiasi. Harga yang diberikan untuk reservasi konferensi adalah harga komersial (Commercial Rates).

\section{Tipe dan Garansi Reservasi}

Untuk memudahkan penanganannya, reservasi dibedakan menjadi dua jenis, yaitu Reservasi Bergaransi (Guaranteed Reservation) dan Reservasi tidak Bergaransi (Non-Guaranteed Reservation). Berikut ini penjelasan selengkapnya:

a. Reservasi Bergaransi

Resevasi bergaransi atau guaranteed reservation adalah suatu pemesanan yang disertai dengan jaminan. Tujuan dari penjaminan ini adalah untuk mendapatkan kepastian atas pemesanan yang telah dilakukan. Jaminan diperlukan untuk meminimalisasi kemungkinan kerugian akibat tindakan pemesanan yang telah memesan tetapi tidak datang tanpa pemberitahuan (no show). Sistem jaminan juga sangat efektif diterapkan terutama saat tingkat kebutuhan sedang tinggi. (Peak Season/High Season).

Suatu reservasi dapat dikatakan digaransi apabila telah diberikan jaminan yang berupa:

1. Pre-payment 
Adalah pembayaran yang dilakukan oleh para pemesan untuk segala pemesanan yang dipesan sebelum mereka mempergunakan fasilitas tersebut.

2. Credit Card

Jaminan pemesanan dengan mengunakan tagihan kartu kredit. Pada saat reservasi petugas hanya menanyakan nama dan nomor kartu kredit. Ini hal yang paling umum digunakan untuk saat ini.

3. Advance Deposit Jaminan pembayaran yang dikirimkan/dibayarkan oleh pemesan dalam jumlah tertentu, paling sedikit setengah dari harga pesanan.

4. Kontrak Kesepakatan (Corporate)

Jaminan yang disertai kesepakatan kontrak antara pihak penyedia dengan suatu perusahaan, sebuah bentuk kerjasama dimana perusahaan menyetujui untuk membayar sejumlah pesanan. Pembayaran tersebut dilakukan apabila digunakan ataupun tidak digunakan.

5. Agen Perjalanan (Travel Agent)

Adalah penjaminan pemesanan yang dilakukan oleh pihak agen perjalanan. Alat yang dipakai untuk penjaminan berbentuk voucher.

b. Reservasi Tidak bergaransi

Reservasi tidak bergaransi atau non-guaranteed reservation adalah suatu pemesanan yang tidak disertai jaminan apapun. Pihak penyedia hanya memastikan pesanan yang telah dipesan tersedia sampai pada batas waktu yang telah ditentukan saat tanggal kedatangan. Hal ini sering disebut juga dengan istilah state reservation cancellation time.

\section{Pengertian Jaringan}

Jaringan komputer dapat diartikan sebagai sebuah rangkaian dua atau lebih komputer. Komputer-komputer ini akan dihubungkan satu sama lain dengan sebuah sistem komunikasi. Dengan jaringan komputer ini dimungkinkan bagi setiap komputer yang terjaring didalamnya dapat saling tukar menukar data, program, dan sumber daya komputer lainnya seperti media penyimpanan, printer, dan lain-lain.

\section{Jenis-jenis jaringan :}

1. Local Area Network (LAN)

LAN merupakan jaringan pribadi di dalam gedung atau kampus yang berukuran sampai beberapa kilometer. LAN seringkali digunakan untuk menghubungkan komputer-komputer pribadi dan workstation dalam kantor suatu perusahaan atau pabrik-pabrik untuk memakai bersama sumberdaya dan saling bertukar informasi

2. Metropolitan Area Network (MAN) MAN pada dasarnya sama dengan LAN hanya saja MAN memiliki ukuran yang lebih besar. MAN dapata mencakup kantor-kantor perusahaan yang letaknya berdekatan atau juga sebuah kota dan dapat dimanfaatkan untuk keperluan pribadi atau umum.

3. Wide Area Network (WAN)

WAN jangkauannya mencakup daerah geografis yang luas, seringkali mancakup sebuah negara bahkan benua.

4. Peer To Peer (P2P)

Peer to peer network adalah jaringan komputer yang terdiri dari beberapa komputer (biasanya lebih 
dari 10 komputer). Dalam sistem jaringan ini yang diutamakan adalah penggunaan program, data dan printer secara bersama-sama.

\section{Internet}

Internet awalnya merupakan suatu rencana dari Departemen Pertahanan Amerika Serikat (US Departement of Defense) pada sekitar tahun 60'an. Dimulai dari suatu proyek yang dinamakan ARPANET atau Advanced Research Project Agency Network. Beberapa universitas di Amerika Serikat diantaranya UCLA, Stanford, UC Santa Barbara dan University of Utah, diminta bantuan dalam mengerjakan proyek ini dan awalnya telah berhasil menghubungkan 4 komputer di lokasi Universitas yang berbeda tersebut. Perkembangan ARPANET ini cukup pesat jika dilihat perkembangan komputer pada saat itu. Sebagai gambarannya pada tahun 1977, ARPANET telah menghubungkan lebih dari 100 mainframe komputer dan saat ini terdapat sekitar 4 juta host jaringan yang terhubung pada jaringan ini. Jumlah sebenarnya dari komputer yang terhubung tidak dapat diketahui dengan pasti, karena perkembangan jumlah komputer yang terhubung dengan suatu jaringan semakin lama semakin besar.

Karena perkembangannya sangant pesat, jaringan komputer ini tidak dapat lagi disebut sebagai ARPANET karena semakin banyak komputer dan jaringanjaringan regional yang terhubung. Konsep ini yang kemudian berkembang dan dikenal sebagai konsep Internetworking (jaringan antar jaringan). Oleh karena itu istilah Internet menjadi semakin popular, dan orang menyebut jaringan besar komputer tersebut dengan istilah Internet.

Agar komputer-komputer dalam suatu jaringan dapat berkomunikasi, maka dibutuhkan suatu protokol atau suatu aturan standar komunikasi baik antar komputer maupun antara jaringan komputer. Ada satu protokol yang dikembangkan oleh DARPA (Defense Advanced Research Projects Agency), dalam pengembangan dari ARPANET dan juga digunakan oleh jaringan komputer berbasis sistem operasi UNIX yaitu protokol TCP/IP(Transmission Control Protocol/Internet Protocol).

Protokol TCP/IP ini menjadi standar protokol yang digunakan pada jaringan Internet, karena TCP/IP dikembangkan untuk dapat diterapkan di hampir segala jenis platform komputer, biasa dikenal dengan konsep open system. Ada 4 badan yang bertanggung jawab dalam mengatur, mengontrol serta melakukan standarisasi protokol yang digunakan :

a. Internet Society (ISOC), merupakan badan profesional yang memfasilitasi, mendukung, serta mempromosikan pertumbuhan internet, sebagai infrastruktu komunikasi global untuk riset. Badan ini berurusan tidak hanya dengan aspek-aspek teknis, namun juga aspek politik dan sosial dari jaringan internet.

b. Internet Architecture Board (IAB), merupakan badan koordinasi dan penasehat teknis bagi Internet Society. Badan ini bertindak sebagai review teknis dan editorial akhir semua standar Internet. IAB memiliki otoritas untuk menerbitkan dokumen standar Internet yang dikenal sebagai Request For Comment (RFC). Tugas lain dari IAB ialah mengatur angka-angka dan konstanta yang digunakan dalam protokol Internet ( nomor port TCP, kode protokol IP, dan lain-lain).

c. Internet Engineering Task Force (IETF), ialah badan yang 
berorientasi untuk membentuk standar Internet. IETF ini dibagi dalam 9 kelompok kerja (misalnya aplikasi, reouting dan addressing, keamanan komputer) dan bertugas menghasilkan standar-standar Internet.

d. Internet Research Task Force (IRTF), ialah badan yang memiliki orientasi pada riset-riset jangka panjang.

Selain itu untuk mempermudah proses pembagiannya, maka IP address dikelompokkan ke dalam kelas-kelas. Hal ini dilakukan untuk memudahkan pendistibusian pendaftaran IP address. Dengan memberikan sebuah ruang nomor jaringan (beberapa blok IP address) kepada Internet Service Provider (ISP) di suatu area diasumsikan pengananan komunitas lokal tersebut akan lebih baik, dibandingkan dengan jika setiap pemakai individual harus meminta IP address ke otoritas pusat, yaitu Internet Assigned Numbers Authority (IANA). Pembagian kelas-kelas IP address didasarkan pada dua hal: network ID dan host ID dari suatu IP address. Setiap IP address selalu merupakan sebuah pasangan dari networkID (identitas jaringan ) dan host-ID (identitas host dalam jarinangan tersebut). Network-ID ialah bagian dari IP address yang digunakan untuk menunjukkan jaringan tempat komputer ini berada. Sedangkah host-ID ialah bagian dari IP address yang digunakan untuk menunjukkan workstation, server, router, dan semua host TCP/IP lainnya dalam jaringan terserbut. Dalam satu jaringan, host-ID ini harus unik (tidak boleh ada yang sama).

\section{Analisis Sistem}

Menurut Jogiyanto, H.M (2005:129), analisis sistem dapat didefinisikan sebagai berikut: "Analisis sistem adalah sebagai penguraian dari suatu sistem informasi yang utuh kedalam bagianbagian komponennya dengan maksud untuk menklasifikasi dan mengevaluasi permasalahan-permasalahan,

kesempatan-kesempatan, hambatanhambatan yang terjadi dan kebutuhankebutuhan yang diharapkan sehingga dapat diusulkan perbaikanperbaikannya".

Dalam tahap analisis sistem terhadap langkah-langkah dasar yang harus dilakukan oleh analisis sistem sebagai berikut:

a. Identify, yaitu mengidentifikasi masalah, merupakan langkah pertama yang dilakukan dalam tahap analisis sistem. Masalah dapat didefenisikan suatu pertanyaan yang di inginkan untuk dipecahkan. Masalah inilah yang menyebabkan sasaran dari sistem tidak dapat tercapai. Oleh karena itulah pada tahap analisis sistem, langkah pertama yang harus dilakukan oleh analisis sistem adalah mengidentifikasi terlebih dahulu masalah-masalah yang terjadi.

Tugas-tugas yang harus dilakukan adalah :

1. Mengidentifikasi penyebab masalah

2. Mengidentifikasi titik keputusan

3. Mengidentifikasi personilpersonil kunci.

b. Understand, yaitu memahami kerja dari sistem yang ada, langkah kedua dari analisis sistem adalah memahami kerja dari sistem yang ada. Langkah ini dapat dilakukan dengan mempelajari secara terinci bagaimana dari sistem yang ada beroperasi dan biasanya diperlukan 
data yang di peroleh dengan cara melakukan penelitian.

Dalam langkah ini ada beberapa tugas yang perlu dilakukan, yaitu:

1. Menentukan jenis penelitian merencanakan jadwal penelitian

2. Membuat penugasan penelitian

3. Membuat agenda wawancara

4. Mengumpulkan hasil penelitian

c. Analyze, yaitu menganalisis sistem, langkah ini dilakukan berdasarkan data yang telah diperoleh dari hasil penelitian yang telah dilakukan.

Tahap ini meliputi:

1. Menganalisis kelemahan sistem : menganalisis distribusi pekerjaan, menganalisis pengukuran pekerjaan, menganalisis keandalan, menganalisis dokumen, menganalisis laporan dan menganalisis teknologi.

2. Menganalisis kebutuhan informasi pemakai/manajemen.

d. Report, yaitu membuat laporan hasil analisis

Langkah ini dilakukan dengan membuat laporan hasil analisis untuk dipakai sebagai rancangan selanjutnya.

\section{Alat Bantu Analisa Sistem}

A. Flow Map

Adalah campuran peta dan flowchart, yang menunjukan pergerakan benda dari satu lokasi ke lokasi lain, seperti jumlah orang dalam migrasi, jumlah barang yang diperdagangkan, atau jumlah paket dalam jaringan. Flowmap menolong analisis dan programmer untuk memecahkan masalah ke dalam segmen-segmen yang lebih kecil dan menolong dalam menganalisis alternaitf-alternatif lain dalam pengoprasian.

\section{B. Data Flow Diagram ( DFD )}

Diagram Alir Data (DAD) atau Data Flow Diagram (DFD) adalah suatu diagram yang menggunakan notasi-notasi untuk menggambarkan arus dari data sistem, yang penggunaannya sangat membantu untuk memahami sistem secara logika, tersruktur dan jelas.

DFD merupakan alat bantu dalam menggambarkan atau menjelaskan DFD ini sering disebut juga dengan nama Bubble chart, Bubble diagram, model proses, diagram alur kerja, atau model fungsi. 


\section{ANALISA SISTEM BERJALAN}

\section{Flow Map Dokumen Sistem Berjalan}

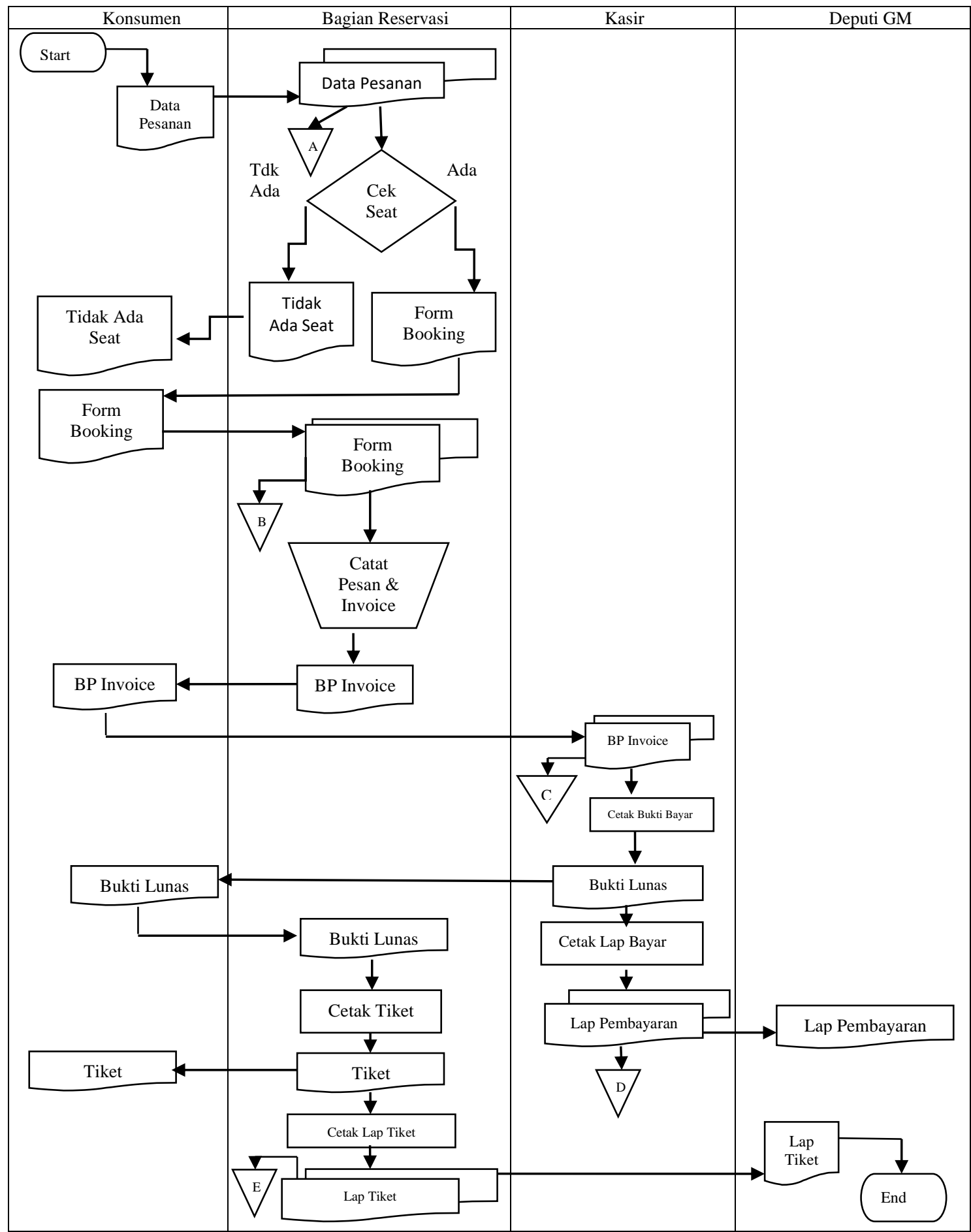

Gambar Flowmap Sistem Berjalan
A : Arsip Data Pesan
B : Arsip Form Booking
$\mathrm{C}$ : Arsip BP Invoice
D : Arsip Lap Pembayaran
E : Arsip Lap Tiket 


\section{Prosedur Sistem Berjalan}

\section{a. Proses Pemesanan}

Konsumen yang akan memesan tiket datang langsung ke bagian reservasi dengan memberikan data manifet pemesanan (MP). Setelah itu bagian reservasi melakukan pengecekan available seat yang masih tersedia di tanggal yang diinginkan penumpang. Jika tidak tersedia seat maka konsumen diberikan informasi. Jika masih tersedia available seat yang diinginkan konsumen, konsumen diberikan form booking (FB), setelah mengisi FB bagian reservasi akan memberikan bukti pemesanan (BP) dan invoice kepada konsumen. b. Proses Pembayaran

Konsumen melakukan pembayaran ke bagian kasir dengan memberikan bukti pemesanan (BP) dan invoice. Setelah melakukan pembayaran, bagian kasir akan memberikan tanda bukti lunas (BL) kepada konsumen. Kemudian konsumen memberikan BL ke bagian reservasi untuk pencetakan tiket, maka reservasi akan memberikan tiket kepada konsumen.

c. Proses Laporan

Laporan dibuat berdasarkan data pembayaran dan data tiket yang dicetak. Laporan dikirimkan kepada Deputi GM.

\section{Data Flow Diagram (DFD) Sistem Berjalan \\ Diagram Konteks Sistem Berjalan}

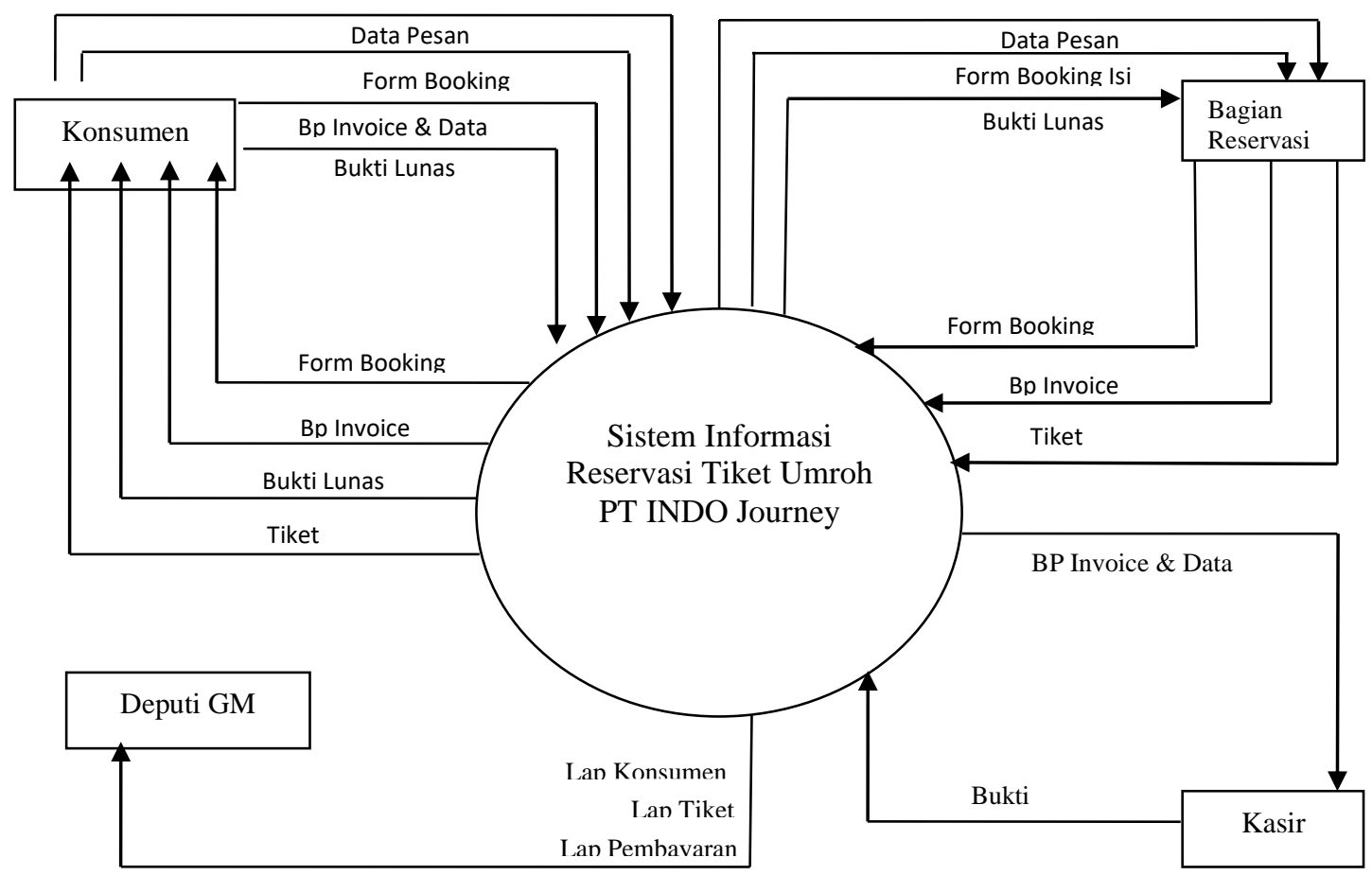

Gambar Diagram Konteks 
Diagram Overview (Zero) Sistem Berjalan

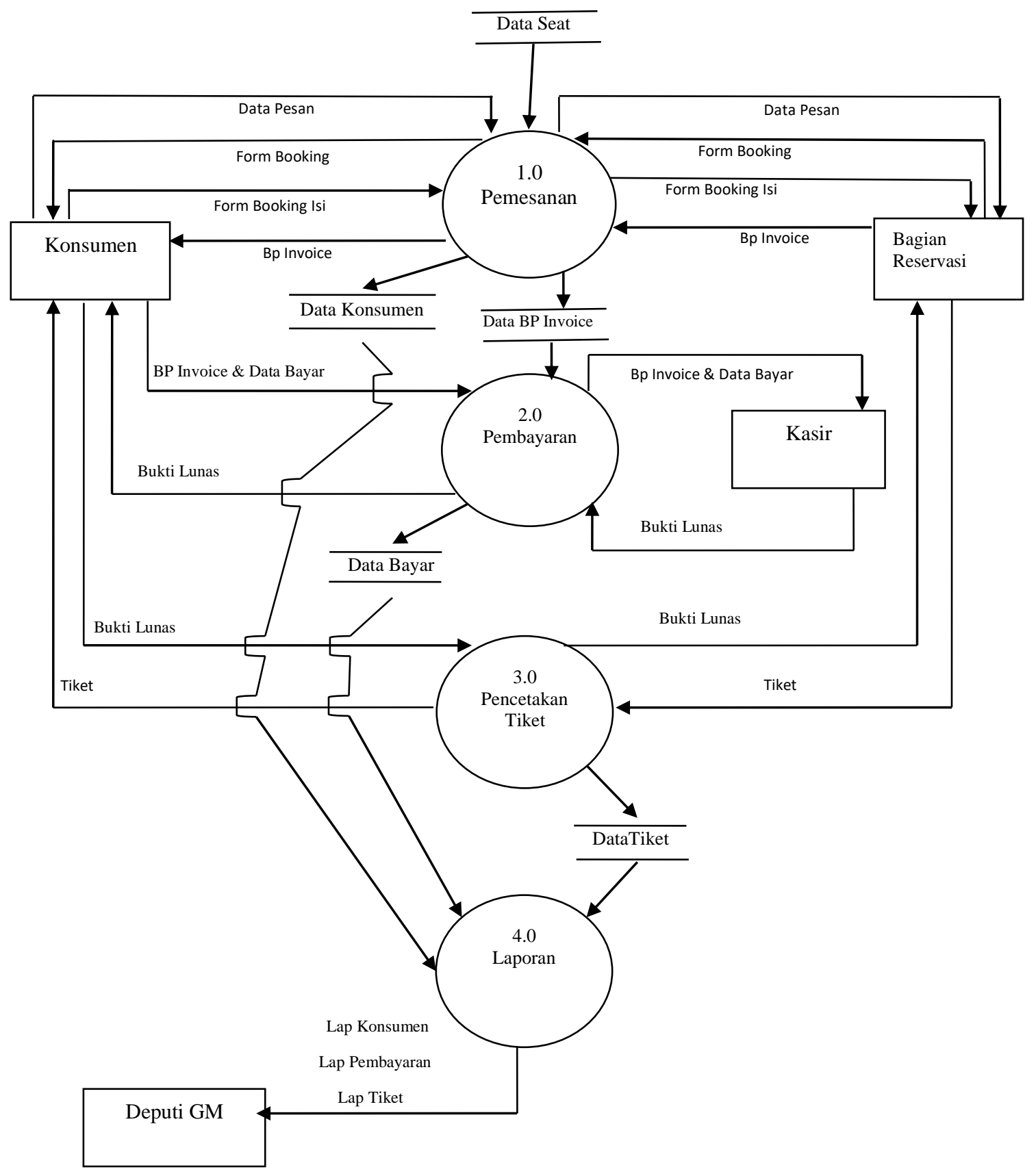

Gambar Diagram Overview (Zero) 
Diagram Rinci Sistem Berjalan

1. Diagram Rinci Proses 1.0

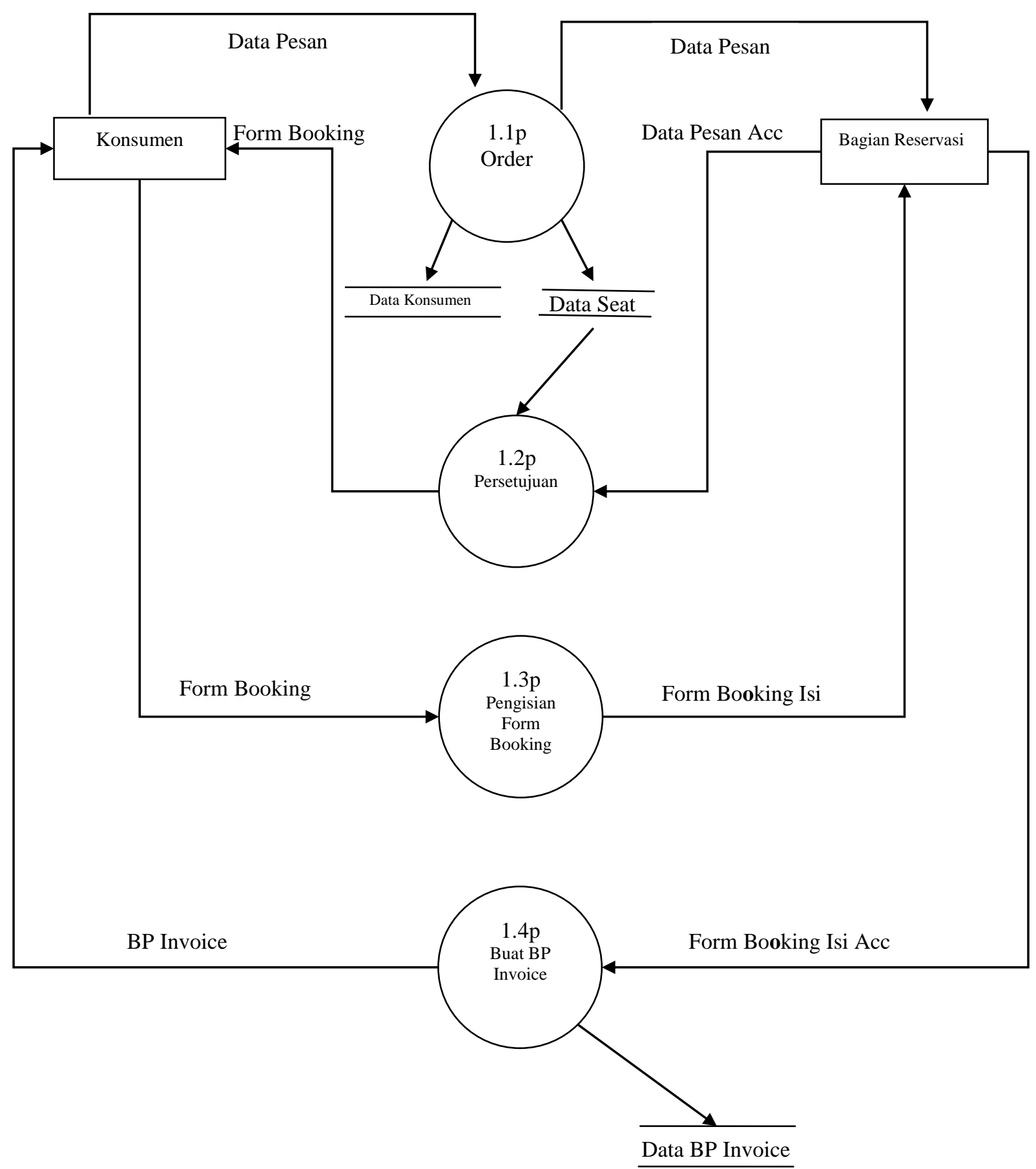

Gambar Diagram Rinci Proses 1.0 
2. Diagram Rinci Proses 2.0

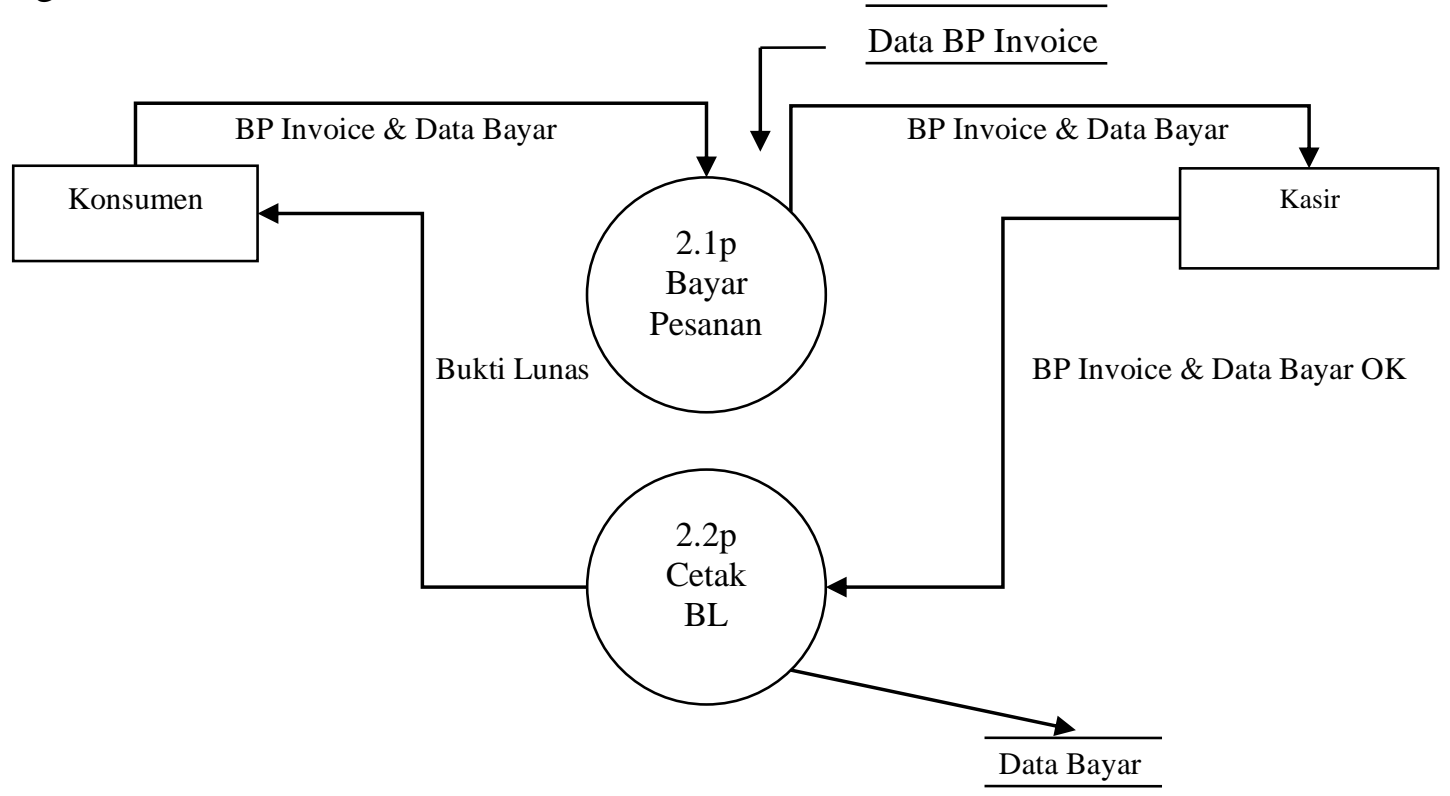

Gambar Diagram Rinci Proses 2.0

3. Diagram Rinci Proses 3.0

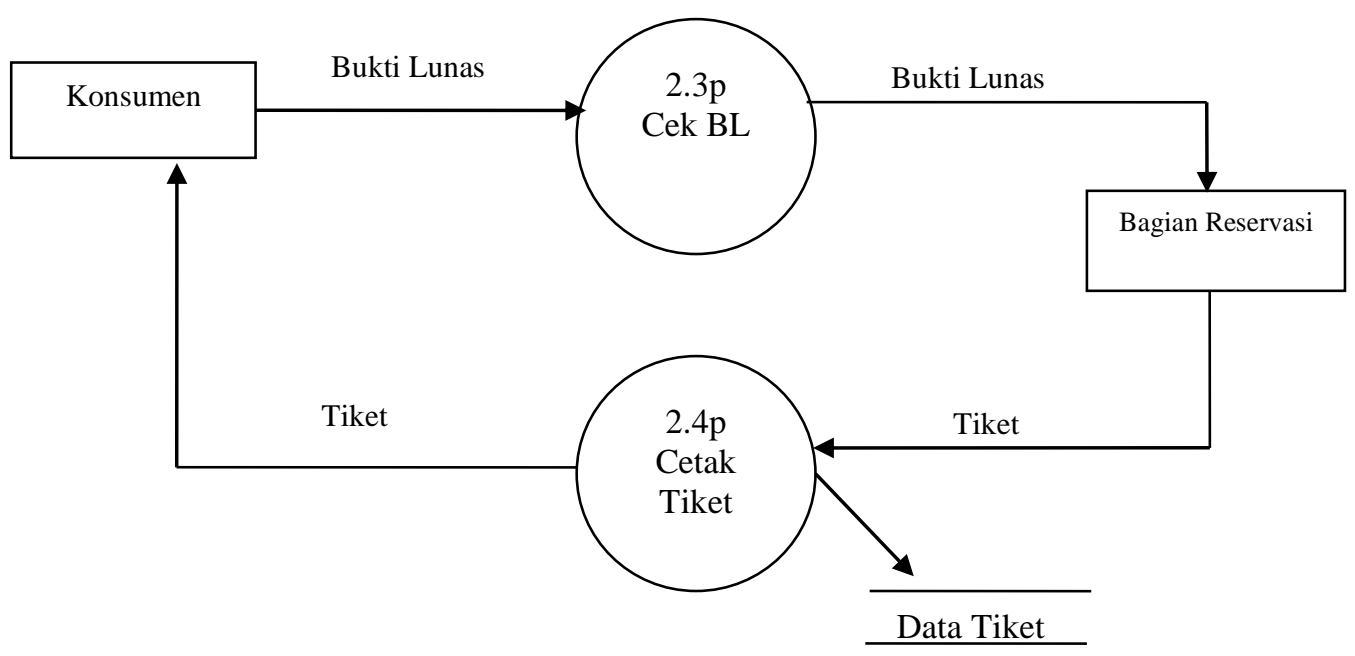

Gambar Diagram Rinci Proses 3.0 


\section{Analisa Dokumen Sistem Berjalan}

1. Analisa Dokumen Masukan

a) Nama Masukan : Data Pesan

Fungsi : Sebagai sumber data pemesanan dan bahan untuk pengecekan available seat

Sumber : Konsumen

Tujuan : Bagian reservasi

Media : Kertas

Format : Terlampir

Frekuensi : Setiap awal terjadi transaksi pemesanan

Volume : Tidak tetap

b) Nama Masukan : Form

Booking

Fungsi : Mencatat jumlah pesanan dan untuk pembuatan bukti pemesanan dan invoice

Sumber : Konsumen

Tujuan : Bagian reservasi

Media : Kertas

Format : Terlampir

Frekuensi : Setiap awal terjadi transaksi pemesanan

Volume : Tidak tetap

c) Nama Masukan : BP Invoice \& Data Bayar

Fungsi : Untuk

Pembayaran

Pemesanan

Sumber : Konsumen

Tujuan : Kasir

Media : Kertas

Format : Terlampir

Frekuensi: Setiap konsumen ingin melakukan pembayaran

Volume : Tidak tetap d) Nama Masukan : Bukti Lunas

Fungsi : Sebagai bukti agar konsumen bisa mencetak tiket

Sumber : Konsumen

Tujuan : Bagian Reservasi

Media : Kertas

Format : Terlampir

Frekuensi: Setiap konsumen ingin melakukan pembayaran

Volume : Tidak tetap

2. Analisa Dokumen Keluaran

a) Nama Keluaran : BP Invoice

Fungsi : Sebagai bukti pemesanan dan jumlah tagihan yang harus dibayar

Sumber : Bagian Reservasi

Tujuan : Konsumen

Media : Kertas

Format : Terlampir

Frekuensi : Setiap terjadi transaksi pemesanan

Volume : Tidak tetap

b) Nama Keluaran : Bukti Lunas

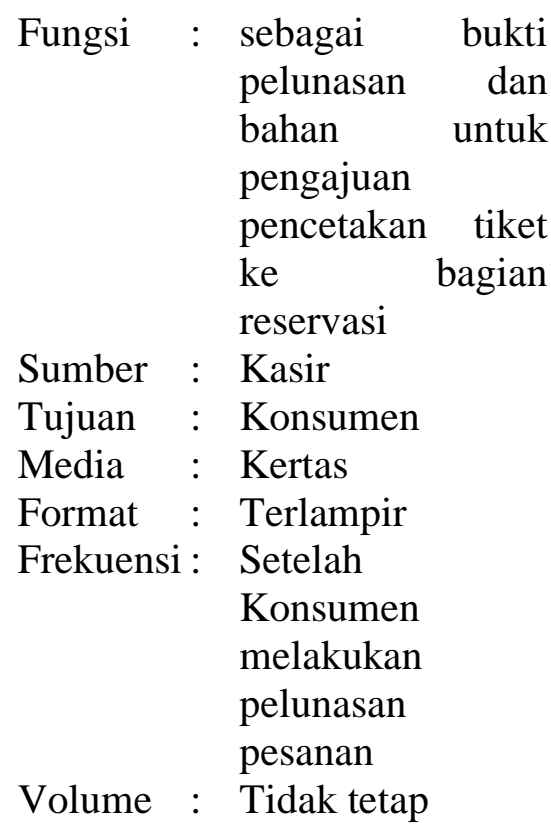


c) Nama Keluaran : Tiket

Fungsi : Sebagai hasil dari pemesanan yang sudah lunas dan sebagai bukti agar bisa mengikuti penerbangan

Sumber : Bagian Reservasi

Tujuan : Konsumen

Media : Kertas

Format : Terlampir

Frekuensi : Setelah konsumen menunjukkan bukti lunas

Volume : Tidak tetap

d) Nama Keluaran : Laporan

Pencetakan tiket

Fungsi : Sebagai bahan laporan jumlah pencetakan tiket

Sumber : Bagian Reservasi

Tujuan : Deputi GM

Media : Kertas

Format : Terlampir

Frekuensi : Per Minggu setelah keberangkatan pesawat

Volume : Tidak tetap

e) Nama Keluaran : Laporan Pembayaran

$\begin{array}{lll}\text { Fungsi } & \text { Sebagai bahan } \\ & \begin{array}{l}\text { laporan dari } \\ \text { penjualan tiket }\end{array} \\ \text { Sumber }: & \text { Kasir } \\ \text { Tujuan }: & \text { Deputi GM } \\ \text { Media }: & \text { Kertas } \\ \text { Format : } & \text { Terlampir } \\ \text { Frekuensi : } & \text { Per Minggu } \\ & \begin{array}{l}\text { setelah } \\ \text { keberangkatan } \\ \text { pesawat } \\ \text { Tidak tetap }\end{array}\end{array}$

\section{Analisa Permasalahan Sistem Berjalan}

Setelah melakukan analisis terhadap sistem informasi reservasi tiket umroh di PT XYZ yang sedang berjalan penulis mendapati beberapa permasalahan yang ada pada sistem tersebut:

1. Belum adanya sistem yang terkomputerisasi dan otomatis yang dapat membuat pekerjaan lebih efisien.

2. Proses reservasi masih dilakukan secara manual sehingga konsumen harus datang ke kantor.

3. Proses pengecekan dan penginputan data available seat masih dilakukan secara manual menyebabkan tidak adanya efisiensi waktu.

4. Proses pembuatan laporan masih manual dengan mengumpulkan data dari pembayaran dan pencetakan tiket, sehingga menghabiskan cukup banyak waktu.

5. Proses pencetakan tiket yang tidak efisien karena setelah membayar, konsumen harus kembali lagi ke bagian reservasi.

\section{PENUTUP}

\section{Kesimpulan}

Dari hasil analisa yang sudah dibahas sebelumnya maka dapat ditarik beberapa kesimpulan:

1. Semua proses masih dilakukan secara manual, dari proses pengolahan data untuk database available seat sampai ke proses laporan, sehingga tidak memenuhi efisiensi dan efektifitas pekerja sebagai mana diharapkan.

2. Sistem database available seat yang diterapkan sekarang tidak memudahkan dalam pengecekan dan penginputan. Bagian reservasi harus mengecek dulu secara manual, sehingga proses pencarian avalilable seat akan memakan 
waktu yang lama dan rentan kesalahan dalam pencarian tiket.

3. Sistem yang belum terkomputerisasi dan masih bersifat manual menyebabkan simpanan file tersebar dan banyaknya tumpukantumpukan berkas. Hal tersebut mengakibatkan tidak adanya jaminan untuk keutuhan penyimpanan berkas, baik softcopy maupun hardcopy.

4. Tidak ada penyajian jadwal keberangkatan secara sistematis berdampak pada tidak leluasanya konsumen dalam melihat informasi mengenai jadwal keberangkatan, karena belum tersaji secara sistematis.

5. Kurangnya media promosi yang digunakan untuk menjangkau masyarakat secara luas.

6. Kurangnya kualitas SDM yang ada jika diadakan pengembangan sistem informasi.

7. Belum adanya website perusahaan yang berguna sebagai pelayanan informasi dan pemasaran secara luas.

8. Pembuatan laporan memakan waktu yang lama dengan mengumpulkan bahan-bahan laporan terlebih dahulu dari pembayaran dan pencetakan tiket.

9. Masih sering terjadinya error dalam pemesanan tiket dan pembuatan laporan oleh karyawan.

10. Pimpinan tidak dapat secara leluasa melihat perkembangan kemajuan perusahaan kapan saja diinginkan, karena laporan harus dibuatkan terlebih dahulu.

Dari hasil kesimpulan analisa tersebut maka sangat disarankan kepada PT XYZ untuk dapat melakukan:

1. Membuat suatu sistem informasi reservasi tiket yang berbasis web pada PT XYZ, sehingga konsumen tidak perlu datang langsung ke kantor dan dapat melihat jadwal keberangkatan secara online.

2. Membuat suatu sistem pengolahan database yang lebih terkomputerisasi untuk memudahkan dalam proses pengecekan seat dan pencarian data yang lebih cepat. Data yang tersusun rapi membuat pelayanan akan informasi baik kepada konsumen maupun pimpinan akan lebih cepat serta pengendalian laporan akan lebih mudah.

3. Membuat website perusahaan sehingga pelayanan akan informasi dan pemasaran lebih efektif. Hal tersebut juga merupakan wadah media promosi untuk peningkatan pelayanan yang prima kepada konsumen dan pemasaran yang efektif bagi perusahaan.

4. Diperlukan karyawan atau tenaga khusus untuk pengelolaan sistem informasi reservasi berbasis web dan pengolaan database agar dapat berjalan dengan baik.

5. Disarankan dalam pengembangan sistem juga diikuti dengan pengembangan sumber daya manusia. Untuk itu, perlu adanya pelatihan khusus pengelolaan sistem informasi berbasis web untuk karyawan lama, sehingga tidak aka nada kesulitan jika ada peralihan sistem dari sistem manual ke sistem komputerisasi berbasis web.

6. Menerapkan sistem informasi terkomputerisasi akan meminimalkan terjadinya error dalam pembuatan laporan.

7. Menerapkan suatu sistem informasi yang terkomputerisasi secara otomatis pada pembuatan laporan penjualan, sehingga bagi pimpinan dapat memantau kemajuan perusahaan kapanpun dan 
dimanapun berada tanpa perlu

dibuatkan terlebih dahulu, karena sistem akan secara otomatis membuatkan summary laporan.

\section{REFERENSI}

Barsasella, Diana “Sistem Informasi Kesehatan”. Jakarta: Mitra Wacana Media. 2010.

Jogiyanto HM, “Analisis \& Desain Sistem Informasi”, Andi Offset, Yogyakarta, 2005.

Kristanto, A. "Perancangan Sistem Informasi dan Aplikasinya", Yogyakarta: Gava Media, 2008.

Awaludin, Muryan dan Natasya. "Analysis Of Ceisa Services User Satisfaction Using The Eucs Method In The Directorate General Of Customs And Excise" Yogyakarta, 2018

Mcleod, R, Schell, "Sistem Informasi Manajemen”. Jakarta: Salemba Empat. 2008.

O’Brien, James,”Diktat Informasi Manajemen” Edisi ke 12 , 2006.

Tata Sutabri, “Sistem Informasi Akuntansi”. Yogyakarta: Andi Offset. 2005.

Wasson, C.S, "System Analysis Desain and Development. Concept, Principles and Practice", USA: Willey Interscience. 2005.

http://adanikmatdisini.blogspot.com/2013/05/jurnal-sistem-informasi-reservasi-tour.html (diakses tanggal 21-Feb-2014).

http://www.edynlaskar.com/2012/09/aps-bab-1-daur-hidup-sistem.html (diakses tanggal 22-Feb-2014).

http://fairuzelsaid.wordpress.com/2010/01/08/analisis-sistem-informasi-diagram-alir-datadad-data-flow-diagramdfd/ (diakses tanggal 20-Feb-2014).

http://infoter-lengkap.blogspot.com/2013/02/flowmap.html (diakses tanggal 21-Feb-2014).

http://kuliah.dinus.ac.id/ika/asi1.html (diakses tanggal 20-Feb-2014).

http://pknaph.blogspot.com/2013/01/macam-macam-reservasi.html (diakses tanggal 20Feb-2014). 
